\title{
THE EFFECT OF CORPORATE GOVERNANCE ON AUDIT REPORT TIMELINESS IN INDONESIA
}

\author{
Darryl Lirungan Senny Harindahyani \\ University of Surabaya
}

\author{
Senny Harindahyani \\ University of Surabaya \\ senny.h@staff.ubaya.ac.id
}

\begin{abstract}
Financial Statements could be useful for the readers to make a decision. In order to rely on Financial Statements to make a decision, the Financial Statements should be relevant. To enhance the relevance of the Financial Statements, the Financial Statements should be published in a timely manner. This research utilizes the data of listed companies on the Indonesia Stock Exchange for period 2013 - 2016. The purpose of this research is to determine the effect of corporate (internal and external indicators) on audit report timeliness. The methodology used in this research is multiple linear regression. In conclusion, the result of this research suggested that board of commissioners independence, audit committee size, audit committee meeting, firm performance, auditor type, and audit opinion have significant association with audit report timeliness. Meanwhile, audit committee qualification and audit tenure do not have significant association with audit report timeliness. In addition, the result suggested that audit tenure weaken the relationship between auditor type and audit report timeliness.
\end{abstract}

\section{Keywords: Audit Report Timeliness, Corporate Governance, Internal and External Indicators}

\section{INTRODUCTION}

It cannot be denied that the most reliable source and reference of accounting information available to external users is audited financial statements (Alkhatib and Marji; 2012). One qualitative characteristic clearly expressed with the Conceptual Framework for Financial Reporting is relevance. As stated by FASB, concept Statement 2, for the financial information to be useful, it must be both relevant and reliable. Alfredson et al. (2009) argue that in order to have relevance, financial information must have a quality that influences users' economic decision. To be relevant and of economic value, the financial information contained in the year end final statement should be disclosed in a timely manner and delivered to users as soon as practicable after the fiscal year-end (Alkhatib and Marji, 2012; Al-Ajmi, 2008).

In Indonesia, Law No. 8/1995 clearly stated that listed companies are required to submit the audited financial statements periodically to BAPEPAM. According to Head of OJK Decree No. 29/POJK.04/2016, the listed companies must submit the audited financial statements to OJK at the end of the fourth months after the end of the fiscal year at the latest. In submitting the audited financial statements in timely manner is not easy, proven by there are still a lot of listed companies that are late to submit the audited financial statements to BAPEPAM. In 2012, there are 52 listed companies that are late to submit the audited financial statements (Syafina, 2013). In 2016, there are 16 listed companies that are late in submitting the audited financial statements (Sugianto, 2017).

Delays in reporting financial information will clearly impact on the effectiveness of reports. The timeliness of audit reports is becoming an important issue as the timing and 
delivery of the reports will affect the relevance of financial statements (Nelson and Shukeri, 2011). Audit report timeliness is commonly measured as the number of days from the year end to the date of the audit report, and is also known as audit report lag. The audit report timeliness is found to have a great impact on financial reporting timeliness and it has become a main concern for regulators and policy makers to investigate the possible factors that may influence audit report timeliness.

Moreover, strong corporate governance mechanisms may improve financial reporting quality such as the strength of the board of commissioners and audit committees (AC). Whereby, Abbott et al. (2004) argued that the audit committee is reported to be significantly associated with the quality of the financial reports since it potentially affects the auditor's risk assessments. Moreover, premised on agency theory, Fama and Jensen (1983) concluded that a firm's internal governance plays an important role in shaping and effectively enhancing the operations of its internal control system and finnaly reduce the audit report timeliness.

Therefore, this study aims to investigate the impact of corporate governance mechanisms on audit report timeliness. The author predicts that strong corporate governance will reduce client-related risks and hence reduce the timing and extent of substantive testing.

Past study found that the proportion of outside directors had a significant positive impact on the effectiveness monitoring function in the company, the more effective it will be in monitoring management behavior; thus, reduce the nature of inherent risk which at the end reduce the audit report lag (Afify, 2009; Salleh et al., 2006; O' Sullivan, 2000). Cohen et al. (2002) argued that if the structure of the client's governance has effectively implemented a strong monitoring and strong strategic perspective, the more efficient audit work might happen. Hence, it will result in less extent of tests of details and a greater assurance of the financial statements integrity. Contradictory with those researches, a large board independence may create communication and coordination problems and hence its effectiveness and monitoring efficiency declines (Dimitropoulos and Asteriou, 2010; Lipton and Lorsch, 1992). However, Nelson and Shukeri (2011) found there is no association between board of commissioners independence and audit report lag.

Naimi et al. (2010) documented that firms with more members in the audit committee and more frequent audit meetings are more likely to produce audit reports in timely manner. Abbott et al. (2004) argued that larger audit committee size, higher meeting frequency, and more qualified members will ensure the internal control and eventually reduce the audit report lag. However, Nelson and Shukeri (2011) found that audit committee meeting and qualification have no association with the audit report lag.

The study examines the effect of internal and external determinants of corporate governance in audit report timeliness with evidence that shows an association between audit report timeliness and the strength of a client's corporate governance and, subsequently, this substantiates the role of corporate governance in financial reporting and the auditing process. Furthermore, the author would like to add firm performance for the independent variables. Nelson and Shukeri (2011) argued that firm performance has significant and negative association with audit report lag. However, Saemargani and Mustikawati (2015) and Alkhatib and Marji (2012) found that the higher the probability of a firm, the longer the audit report lag. Firm performance is not corporate governance; however, to have a great performance, the management will do their best. In order to ensure that the management will do their best to have great performance, the company needs a good corporate governance to control management's activities.

Moreover, the author would like to analyze the impact of external corporate governance, which are the auditor type and audit opinion in relationship with the audit report timeliness. Nelson and Shukeri (2011), Iyoha (2012), and Al-Ajmi (2008) have documented that auditor's type is found to have negatively significant relationship with audit report 
timeliness. However, Hassan (2016), Dibia and Oncwuchekwa (2013), and Turel (2010) found that Big Four firms perform the audit work longer than the Non-Big Four firms. Nelson and Shukeri (2011) and Turel (2010) found that audit opinion has a negative significant association with the audit report lag. If the firm get clean unmodified opinion (good news), then the audit report lag will be shorter. Nevertheless, Saemargani and Mustikawati (2015), Panjaitan et al. (2013), and Kartika (2009) found the contradictory results.

Next, the author would like to add a new variable that might be considered associated with audit report timeliness, which is audit tenure. Dao and Pham (2014) found that there is a negative relationship between audit tenure and audit report timeliness. The longer the audit tenure, the faster the audit report timeliness. This finding is in line with Habib and Bhuiyan (2011), Lim and Tan (2010), and Lee et al. (2009) that found negative relationship between audit tenure and audit report lag. However, Lai and Cheuk (2005) did not find any evidence on longer audit report lag resulting from audit firm rotation. Thus, this research is special due to the combination of two main researches (Nelson and Shukeri, 2011; Dao and Pham, 2014). Also, the addition of moderating variable to analyze the effect of audit tenure on the relationship between firm performance, auditor type, and audit opinion with the audit report timeliness.

Based on the discussion above, there are a lot of factors that affect the audit report timeliness whether it is from internal or external of the company and all of the researches mostly not from Indonesia. Thus, the author would like to conduct a further analysis about the association between corporate governance (internal and external indicators) and audit report timeliness by using the data from listed company on the Indonesia Stock Exchange for the period of 2013-2016 all sectors.

\section{THEORETICAL FRAMEWORK AND HYPOTHESIS DEVELOPMENT}

\section{Board of Commissioners Independence}

There is an ongoing debate among accounting researchers as whether large or small board independence are more effective in monitoring management and improving the quality of corporate reporting. It is expected that larger board independence are more efficient in executing their responsibilities as the collective experience and expertise of the board will increase (Akhtaruddin et al., 2009) and such large boards are more likely to reduce the dominance of the management (Hussainey and Wang, 2010).

The Agency Theory; however, suggests that there is an upper limit to the number of board independence. A large number of board independence may create communication and coordination problems and hence its effectiveness and monitoring efficiency declines (Dimitropoulus and Asterious, 2010; Lipton and Lorsch, 1992). Moreover, a large board independence creates less participation and is less able to reach an agreement (Mak and $\mathrm{Li}$, 2001; Dalton et al., 1999). Similarly, Wu et al. (2008) has argued that Taiwanese listed firms with more board members are expected to have longer audit delay. Apadore and Noor (2013) found that more independent board, it tends to be as an impetus for problem such as arguments or feud because of the different opinions and suggestions and this will prolong with the audit report timeliness. Yaacob and Che-Ahmad (2012) also found positive association between board independence and audit report timeliness.

\section{H1. There is a positive association between board of commissioners independence and audit report timeliness.}

\section{Audit Committee}

The effectiveness of an audit committee increases when the size of the committee increases because it has sufficient resources to address the issues faced by the company 
(Rahmat, et al., 2009). Be'dard and Gendron (2010) indicated that the audit committee size, independence, competency and meetings have greatest impact on financial reporting quality. This is supported by Naimi et al. (2010), who documented that firms with more members in the audit committee are more likely to produce audit reports in a timely manner. Thus, strong audit committee in terms of its size will ensure the internal control and procedures of the company is reduced. Therefore, it will reduce the auditor working hours and subsequently reduce the ART.

Audit committee must carry out activities effectively through an increased frequency of meeting in order to maintain its control functions (Be'dard et al.,2004). Mohamad-Nor et al. (2010) have investigated the relation between an audit committee that meets at least quadruple a year and audit report lag. Be'dard and Gendron (2010), they indicate that the audit committee meetings have greatest impact on financial reporting quality. This is supported by Naimi et al. (2010), who document that firms with more frequent audit committee meetings are more likely to produce audit reports in a timely manner. Audit committee expertise is important in order to deal effectively with external auditors; it is because audit committee often act as the mediator between the management and auditors (Hashim and Rahman, 2011).

\section{H2a. There is a negative association between audit committee size and audit report timeliness.}
H2b. There is a negative association between frequency of audit committee meeting and audit report timeliness.

\section{H2c. There is a negative association between audit committee qualification and audit report timeliness.}

\section{Firm Performance}

Prior research has found that firms that experience losses for the period would result in longer audit report lag (Ashton et al., 1989; Givoly and Palmon, 1982; Ismail and Chandler, 2004). Prior studies also reported that firms experiencing losses for the periods are expected to have a longer audit delay as compared to the ones reporting a profit. There are some underlying reasons to the expectation of firm performance with audit report lag. Firms that have bad news - the ones which have made losses - tend to delay their financial statement release because they want to avoid reporting the bad news to their shareholders and investors, and hence avoid jeopardizing their firm's reputation and performance.

However, for firms that experience profit, the management wants the auditor to complete their annual report in a short time because they want to report the good news to their shareholders. Moreover, the auditor may take a longer period to audit firms that incurred losses because of the associated business risk (Afify, 2009) and consequently increase the ART. Nelson and Shukeri (2011) found out that probability is significantly associated with audit report timeliness, suggesting that companies with good news report faster that companies with bad news.

\section{H3. There is a negative association between firm performance and audit report timeliness.}

\section{Auditor Type}

Afify (2009) showed that larger audit firms have a stronger motivation to complete their audit work on time in order to maintain their reputation and name. The large audit firms normally have more efficient audit teams as they have more resources to conduct trainings for their staff and are also able to employ more powerful audit technologies which reduce the time of audit work (Owusu-AnsahandLeventis, 2006). Giroux and McLelland (2000) found 
that Big Four firms completed their audit work faster than the non Big Four firms. Thus, it is expected that large audit firms (Big Four firms) will perform faster audit work as compared to the small audit firms (non Big Four firms) as Big Four firms have more resources compared to non Big Four firms. Given with more resources, the auditors in Big Four firms are able to complete the audit work on time and consequently reduce the ART.

Nelson and Shukeri (2011) argued that auditor type has a significant negative association with audit report lag and subsequently provides evidence that companies audited by Big Four firms have a shorter audit report lag due to have more resources, powerful technology, more experienced auditor which enables the audit process to be complemented within a shorter period of time.

\section{H4. There is a negative association between auditor type and audit report timeliness.}

\section{Audit Opinion}

The company that received unqualified audit opinion is said to have proper management and internal control system, thus reducing the time of audit process and procedures (Soltani, 2002). Bamber et al. (1993) argued that the qualified opinions are not likely to be issued until the auditor has spent considerable time and effort in performing additional audit procedures. Moreover, companies always view audit qualified opinion as bad news and might not respond to the auditor's request promptly. It is a symptom of auditormanagement conflict that would also increase audit delay (Che-Ahmad and Abidin, 2008). For the company that received qualified audit opinion, the auditor may need additional time to complete the audit work and thus increase the ART.

\section{H5. There is a negative association between audit opinion and audit report timeliness.}

\section{Audit Tenure}

Prior studies documented that ART is determined by firm and auditor related factors such as firm size, audit effort, audit firm structure and so on. Audit firm tenure is one of the factors found to influence auditors' effectiveness. In fact, empirical evidence shows that audit firms work more effectively (i.e. shorter ART) when there is a long auditor- client relationship (Lee et al., 2009). The reason is that it takes time for audit firms to be familiar with their clients' operations; therefore, initial audit engagement is less efficient than later years' audit engagements. Various discussions have taken place on the topic of whether firms should hire auditors for a long time or there should be a mandatory auditor rotation.Dao and Pham (2014) found that there is a negative relationship between audit tenure and audit report timeliness.

\section{H6. There is a negative association between audit tenure and audit report timeliness.}

Lee et al. (2009) argued that audit firm tenure is one of the factors found to influence auditors' effectiveness. In fact, empirical evidence showed that audit firms work more effectively when there is a long auditor - client relationship. The reason is that it takes time for audit firms to be familiar with their clients' operations. Thus, the researcher would like to use audit tenure as a moderation variable.

Nelson and Shukeri (2011) argued that the companies with higher probability may wish to complete the audit of their accounts as early as possible in order to quickly release their audited annual reports to the public. Also, Big Four firms have more sources, powerful technology, more experienced auditor which enables the audit process to be completed within a shorter period of time. Furthermore, companies that received qualified opinion tend to 
report their financial statement early, because the auditor believed these types of companies do not have much problem.

\section{H7. Audit tenure affects the association between firm performance and audit report timeliness.}

H8. Audit tenure affects the association between auditor type and audit report timeliness.

H9. Audit tenure affects the association between audit opinion and audit report timeliness.

\section{RESEARCH METHODOLOGY}

This research used historical data from the annual report and audited financial statements for the year ended December $31^{\text {st }}$ of all the public companies listed on the Indonesia Stock Exchange (IDX) from 2013 until 2016. This hypothesis testing will examine further analysis of the effect of corporate governance (internal and external) in audit report timeliness with Multiple Linear Regression.

In Table 1, it is shown that there are 2,040 listed companies in total at the beginning of this research. However, after the sample selection process by using Purposive Sampling, there are 12 listed companies that has end of financial statements reporting not on December $31^{\text {st }}, 761$ listed companies that have incomplete data in the Annual Report and Financial Statements, and 6 listed.

Table 1

\section{Sample Selection}

\begin{tabular}{|l|c|c|c|c|c|}
\hline \multicolumn{1}{|c|}{ Criteria } & $\mathbf{2 0 1 3}$ & $\mathbf{2 0 1 4}$ & $\mathbf{2 0 1 5}$ & $\mathbf{2 0 1 6}$ & Total \\
\hline $\begin{array}{l}\text { Companies listed in } \\
\text { Indonesia Stock Exchange }\end{array}$ & 483 & 506 & 517 & 534 & 2,040 \\
\hline $\begin{array}{l}\text { End of Financial } \\
\text { Statements Reporting is } \\
\text { not December 31 st }\end{array}$ & -3 & -3 & -3 & -3 & -12 \\
\hline $\begin{array}{l}\text { Incomplete Annual Report } \\
\text { and Financial Statements }\end{array}$ & -178 & -197 & -196 & -190 & -761 \\
\hline $\begin{array}{l}\text { Total data available used } \\
\text { as sample }\end{array}$ & 302 & 306 & 318 & 341 & 1,267 \\
\hline $\begin{array}{l}\text { Sample data eliminated as } \\
\text { outlier }\end{array}$ & -2 & -1 & -2 & -1 & -6 \\
\hline $\begin{array}{l}\text { Final sample data used in } \\
\text { this research }\end{array}$ & 300 & 305 & 316 & 340 & 1,261 \\
\hline
\end{tabular}

\section{Research Model.}

$$
\begin{aligned}
A R T= & \beta 0+\beta 1(B I N D)+\beta 2(\text { ACSIZE })+\beta 3(\text { ACMEET })+\beta 4(A C Q U A L)+ \\
& \beta 5(F P E R F)+\beta 6(\text { AUDTYPE })+\beta 7(\text { AUDOPIN })+\beta 8(T E N)+ \\
& \beta 9(\text { TENXFPERF })+\beta 10(\text { TENXAUDTYPE })+\beta 11(\text { TENXAUDOPIN })+\varepsilon
\end{aligned}
$$

Explanations:

1. ART is number of days from the interval period of financial year end date to the date of annual report.

2. Board independence (BIND) is the proportion of non-executive directors to the total number of board of commissioners.

3. Audit committee size (ACSIZE) is the total number of audit committee members. 
4. Audit committee meetings (ACMEET) is the number of audit committee meetings held during the financial year.

5. Audit committee qualifications (ACQUAL) is the proportion of audit committee members possessing professional accounting qualifications (CPA, CMA, etc.) or members of any professional accounting bodies (DSAK, IAI, etc.) to the total number of audit committee members.

6. Firm performance (FPERF) is dummy variable that takes the value of 1 for company generates gain and 0 otherwise.

7. Auditor type (AUDTYPE) is dummy variable that takes the value of 1 for Big Four firm and 0 for non Big Four firm.

8. Audit opinion (AUDOPIN) is dummy variable that takes the value of 1 for company receive clean unqualified audit opinion and 0 otherwise.

9. Audit tenure (TEN) is dummy variable that takes the value of 1 for audit tenure $>3$ years and 0 otherwise.

10. TENXFPERF is a moderation variable that describes the effect of audit tenure on the relationship between audit firm performance and audit report timeliness.

11. TENXAUDTYPE is a moderation variable that describes the effect of audit tenure on the relationship between auditor type and audit report timeliness.

12. TENXAUDOPIN is a moderation variable that describes the effect of audit tenure on the relationship between audit opinion and audit report timeliness.

13. $\varepsilon$ is error estimations.

\section{RESULT AND DISCUSSION}

\section{DATA ANALYSIS}

Table 2. below summarizes that there are 1,261 listed companies in total that being used in this research as the final sample. The result shows that the minimum ARL is 12 days and the maximum ART is 182 days. The average ART is 76.185 days which means that average listed companies in Indonesia comply with the law of audit report timeliness more or less 120 days maximum to submit the audited financial statements (Head of OJK Decree No.29/POJK.04/2016) and the standard deviation for ARL is 20.8052. However, there are still some listed companies that do not comply with that law. This evidence suggests that ART still becomes a concern for Indonesian companies in setting financial reporting policy.

Table 2.

\section{Descriptive Statistics}

\begin{tabular}{lcccc}
\hline Variables (N=1,261) & Minimum & Maximum & Mean & SD \\
\hline ARL & 12 & 182 & 76.185 & 20.8052 \\
\hline BIND & 14.29 & 100 & 42.2212 & 12.87489 \\
\hline ACSIZE & 1 & 13 & 3.203 & .8146 \\
\hline ACMEET & 1 & 96 & 8.124 & 8.8826 \\
\hline ACQUAL & .00 & 100 & 12.6715 & 22.08746
\end{tabular}

Note:ARL, number of days from the interval period of financial year end date to the date of annual audit report; BIND, the proportion of non-executive directors to the total number of directors; ACSIZE, number of AC members; ACMEET, the number of audit committee meetings held during the financial year; ACQUAL, the proportion of audit committee members possessing professional accounting qualifications (ACCA, etc.) or members of any professional accounting bodies (MIA, CPA etc.) to the total number of audit committee members. 
Table 3 shows the frequency statistics of dummy variables in this research. Firm performance (FPERF) is the first dummy variable in this research in which shows that there are 266 listed companies that get loss $(21.1 \%)$ and 995 listed companies that get gain (78.9\%). Auditor type (AUDTYPE) is the second dummy variable in shows that there are 721 listed companies that are audited by Non-Big Four Firm (57.2\%) and 540 listed companies that are audited by Big Four Firm (42.8\%). Audit opinion (AUDOPIN) is the third dummy variable in this research in which shows that there are 458 listed companies that have opinion beside unmodified (clean) opinion (36.3\%) and 803 listed companies that have unmodified (clean) opinion (63.7\%). Audit tenure (TEN) is the fourth dummy variable in this research in which shows that there are 361 listed companies that have audit tenure not over 3 years $(28.6 \%)$ and 900 listed companies that have audit tenure $>3$ years $(71.4 \%)$.

Table 3

\section{Frequency Statistics}

\begin{tabular}{lccc}
\hline Variables (N=1,261) & Category & Frequency & Percentage (\%) \\
\hline FPERF & Loss & 266 & $21.1 \%$ \\
\hline AUDTYPE & Gain & 995 & $78.9 \%$ \\
\hline \multirow{2}{*}{ AUDOPIN } & Big Four & 540 & $42.8 \%$ \\
\hline & Non-Big Four & 721 & $57.2 \%$ \\
\hline TEN & Clean Unmodified & 803 & $63.7 \%$ \\
\hline & Others & 458 & $36.3 \%$ \\
\hline
\end{tabular}

Note: FPERF, assigned as 1 for company that incurs profit and 0 for company that incurs loss. AUDTYPE, assigned as 1 for Big Four firm and 0 otherwise; AUDOPIN, assigned as 1 for company received unmodified (clean) audit opinion and 0 otherwise; TEN, assigned as 1 for company that have audit tenure more than 3 years and 0 otherwise.

As the result of the multiple regression linear in Table 4, it can be told that board independence (BIND) has positive significant association (0.0025) with audit report timeliness (ART). It means that the more the board of commissioners independence the longer the audit report timeliness. It might be happened due to the various backgrounds that each independent commissionaire has. Since there are a lot of commissionaires which have different backgrounds, they could argue due to different opinion. As a result, it would longer the audit report timeliness. This finding is in line with Dimitropoulos and Asterious (2010) that stated the big amount of independent commissionaire could create ineffective communication and coordination. Hasan (2016) also found the positive association between the board independence and the audit report timeliness. The larger proportion of the board independence could increase the coordination problems and result in a less meaningful discussion.

In Table 4, the researcher can conclude that audit committee size (ACSIZE) has a negative significant association (0.000) with the audit report timeliness (ARL). It means that the larger the audit committee size, the shorter the audit report timeliness. The audit committee could ensure the internal control of the company is strong. Consequently, it generates positive influence on the auditor's assessment of business and audit risk, planned audit hours and the level of substantive testing and good financial reporting. Therefore, reduce the audit report timeliness (Nelson and Shukeri, 2011). This finding is in line with Rahmat et al. (2009) that found the effectiveness of audit committee could increase when the size of the committee increases because it has sufficient resources to address the issues faced 
by the company. Also, Naimi et al. (2010) suggested that firms with more members in the audit committee are more likely to produce audit reports in a timely manner.

Table 4

Result of Multiple Regression Linear

\begin{tabular}{|c|c|c|c|c|c|}
\hline \multirow[b]{2}{*}{ Model } & \multicolumn{2}{|c|}{$\begin{array}{c}\text { Unstandardized } \\
\text { Coefficients }\end{array}$} & \multirow{2}{*}{$\begin{array}{c}\text { Standardized } \\
\text { Coefficient }\end{array}$} & \multirow[b]{2}{*}{$\mathrm{t}$} & \multirow[b]{2}{*}{ Sig. } \\
\hline & $\mathrm{B}$ & Std.Error & & & \\
\hline (Constant) & 96.526 & 3.327 & & 29.017 & .000 \\
\hline BIND & .121 & .043 & .075 & 2.791 & $.005 * *$ \\
\hline ACSIZE & -2.619 & .693 & -.103 & -3.780 & $.000 * *$ \\
\hline ACMEET & -.322 & .063 & -.138 & -5.1111 & $.000 * *$ \\
\hline ACQUAL & -.014 & .025 & -.015 & -.549 & .583 \\
\hline FPERF & -11.269 & 2.371 & -.221 & -4.753 & $.000 * *$ \\
\hline AUDTYPE & -6.409 & 2.423 & -.152 & -2.645 & $.008 * *$ \\
\hline AUDOPIN & -5.742 & 2.127 & -.133 & -2.700 & $.007 * *$ \\
\hline TEN & -.852 & 2.732 & -.019 & -.312 & .755 \\
\hline TENxFPERF & .769 & 2.918 & .018 & .263 & .792 \\
\hline TENxAUDTYPE & 5.552 & 2.729 & .128 & 2.034 & $.042 *$ \\
\hline TENxAUDOPIN & -1.573 & 2.574 & -.038 & -.611 & .541 \\
\hline
\end{tabular}

The result of Table 4 shows that audit committee meeting has a significant negative association (0.000) with the audit report timeliness. It means the more frequent the audit committee conducts the meeting, the shorter the audit report timeliness. The more frequent the meeting of the audit committee can indicate that the audit committee is diligent in doing their task which is to assist supervisory function of the board of commissioners to oversee the integrity of the company's financial statements (Indonesia Corporate Governance Manual, 2014). This finding is inconsistent with Nelson and Shukeri (2011) that found that audit committee meeting has no association with the audit report timeliness. However, this finding is consistent with Bedard and Gendreon (2010), Naimi et al. (2010), and Abbott et al. (2004) that found frequent audit committee meeting has greatest impact on financial reporting quality, more likely to produce audit reports, and the audit committee will remain informed and knowledgeable about accounting or auditing issues and can direct internal and external audit resources to address the matter in a timely manner. Ika and Gazhali (2012) found that audit committee effectiveness has a strong association with financial reporting quality. The more effective the audit committee, the shorter the audit report timeliness. Audit committee meeting is one of the indicators of the effectiveness of audit committee.

The result of Table 4 indicates that hypothesis $2 \mathrm{c}-$ the audit committee qualification has a negative association with audit report timeliness - is not accepted. It means that there is no significant association between audit committee qualification with audit report timeliness (0.2915). This finding is consistent with Nelson and Shukeri (2011) that argued audit committee qualification has no significant association with audit report timeliness. It might happen due to the light of the strict adherence of listed companies on the enforcement of MCCG (2007), which requires all listed companies to have at least three members and at least one member being a financial expert. In Indonesia, there is also the guidance about the qualification of the audit committee. According to Indonesia Corporate Governance Manual (2014), members of audit committee must be financial or accounting literate. One of the success factor of the audit committee is the aptitude which is the ability and capability of the 
member to do the tasks. The qualification can be used as one factor that determine the aptitude of the audit committee. However, the result shows that there are only few people that take the qualification in accounting. Also, according to the IAI, number of registered accountant in Indonesia is still low compare to the accounting graduates each year.

As shown in Table 4, it can be concluded that hypothesis 3 is accepted in which firm performance has a negative significant association $(0.000)$ with the audit report timeliness. In this research, firm performance is described into gain or loss. Gain will indicate good news, whereas loss will indicate bad news. If the firms generate gain, it is a good news for them and they tend to publish the financial statements in a timely manner or even earlier. However, if the firms do not generate gain (loss), they will tend to postpone the publishing of their financial statements due to the bad news. This finding is consistent with Nelson and Shukeri (2011) that found out profitability is significantly associated with audit report timeliness, suggesting that companies with good news report faster than companies with bad news. Also, Afify (2009) argued that auditor may take a longer period to audit firms that incurred losses because of the associated business risk and resulting in increasing the audit report timeliness.

As shown in Table 4, it can be concluded that hypothesis 4 is accepted, that auditor type has a negative significant (0.004) association with the audit report timeliness. It means that Big Four Firms perform better than Non-Big Four Firms in auditing the firms in Indonesia, because they will be motivated not to lose their reputation to the Non-Big Four Firms. Also, the Big Four Firms have more sufficient resources, such as high technology program, efficient audit team, and more experienced audit team that enable them to conduct the audit process within a shorter period of time. This finding is consistent with Nelson and Shukeri (2011), Afify (2009), Owusu-Ansah and Leventis (2006), Iyoha (2002), Giroux and McLelland (2000) that found the negative association between auditor type and audit report timeliness.

Table 4 shows that hypothesis 5 is accepted, that audit opinion has a negative significant association (0.0035) with audit report timeliness. It means that if the firms get clean unmodified opinion, the audit report timeliness will be shorter. It is because having a clean unmodified opinion can be classified as a good news and there is no reason for the firms to delay the publishing of the independent auditor report. This finding is supported with Nelson and Shukeri (2011) and Turel (2010) argue that firms that received clean unqualified audit opinion are expected to report their financial statements early, because the auditor believed that the firms would not have much problems that need extensive testing in providing their opinion. This finding is also consistent with Soltani (2002), and Bamber et al. (1993). Lee and Jahng (2008) and Ashton et al. (1989) also argued that auditors spend more time on audits when they issue opinions other than clean unmodified opinion.

From Table 4, it can be told that hypothesis 6 is not accepted in which audit tenure has no significant association with the audit report timeliness $(0.3775)$. This finding is inconsistent with Dao and Pham (2014) and Lee et al. (2009) that found negative association between audit tenure and audit report timeliness and show that audit firms work more efficiently when there is a long auditor-client relationship. However, this result is consistent with the research conducted by Lee and Jahng (2008) that found the insignificant association between audit tenure and audit report timeliness indicating long audit tenure does not necessarily increase audit efficiency that would shorten the audit report timeliness.

The result in Table 4 shows that audit tenure effects the relationship between auditor type and audit report timeliness significantly positive. However, the audit tenure does not affect the relationship between audit opinion and firm performance with audit report timeliness. This is an interesting finding, since auditor type has a significant negative association with the audit report timeliness. However, the audit tenure effects that relationship positively. It means that the longer the relationship between the auditor and 
clients, the longer the audit report timeliness. Even though, the auditor is Big Four Firm, if the relationship of the big four firm and clients has been tied for a long time, it will delay the audit report timeliness.

Furthermore, it cannot be denied that Indonesian are tend to behave subjectively with their colleagues. Long audit tenure between the auditor and the clients might indicate that both parties are comfortable with each other because both parties bring benefit to each other. As a result, even though the audit firm is big four firm, if the audit tenure is long enough to create a comfortable relationship, it would result in delaying the audit report timeliness. For hypothesis 7 and 9, the results show the rejection to both hypotheses in which audit tenure does not affect the relation of audit opinion and firm performance with audit report timeliness. It does not matter whether the audit tenure is short or long, it will not affect the relationship between audit opinion and firm performance with audit report timeliness; since the audit tenure in Indonesia cannot be as a relevant and reliable variable due to the high subjectivity of Indonesian that affect the independency of an auditor itself.

\section{CONCLUSION}

The purpose of this study is to determine the effect of corporate governance (internal and external) on audit report timeliness. The internal indicators of corporate governance consist of board of commissioners independence, audit committee size, audit committee meeting, audit committee qualification, and firm performance. The external indicators of corporate governance consist of auditor type, audit opinion, and audit tenure. In addition, the writer would like to know the effect of audit tenure in the relationship between auditor type and audit report timeliness, audit opinion and audit report timeliness, and firm performance and audit report timeliness.

The results show that board of commissioners independence (H1), audit committee size (H2a), audit committee meeting (H2b), firm performance (H3), auditor type (H4), audit opinion (H5) have significant association with audit report timeliness. Also, the audit tenure weakens the association between auditor type and audit report timeliness (H8). However, the audit committee qualification $(\mathrm{H} 2 \mathrm{c})$ and audit tenure $(\mathrm{H} 6)$ have no significant association with the audit report timeliness. The audit tenure has no effect on the association between firm performance (H7) and audit opinion (H9) with the audit report timeliness as well.

In conclusion, corporate governance does affect the audit report timeliness. However, not all of the corporate governance seems to have significant impact on audit report timeliness. It could be a challenge for the regulator to make the listed companies in Indonesia to obey the standard and qualification of the corporate governance. Also, the regulator should have a new way of rule to prevent the auditors to behave not independent due to the long auditor - client relationships.

\section{REFERENCE}

Abbott, L. J.; S. Parker; and G.F. Peter. 2004. Committee Characteristics and Restatements. Auditing: A Journal of Practice and Theory, 23(1), 69-87.

Afify, H.A.E. 2009. Determinants of Audit Report Lag: Does Implementing Corporate Governance Have Any Impact? Empirical Evidence from Egypt. Journal of Applied Accounting Research, Vol. 10 No. 1, pp. 56-86.

Akhtaruddin, M.; M.A. Hossain; M. Hossain; and L. Yao. 2009, Corporate Governance and Voluntary Disclosure in Corporate Annual Reports of Malaysian Listed Firms", Journal of Applied Management Accounting Research, Vol. 7 No. 1, pp. 1-19. 
Alkhatib, K. and Q. Marji. 2012. Audit Reports Timeliness: Empirical Evidence from Jordan, Social and Behavioral Sciences, Vol. 62, pp. 1342-1349.

Al-Ajmi, J. 2008. Audit and Reporting Delays: Evidence From An Emerging Market, Advances in Accounting, Incorporating Advances in International Accounting, Vol. 24 , pp. 217-226.

Alfredson, K., K. Leo, R. Picker, J. Loftus, K. Clark, V. Wise, and M. Dyki. 2009. Applying International Financial Reporting Standards. 2nd ed., John Wiley and Sons Australia Ltd., Milton.

Apadore, K. and M. Noor. 2013. Determinants of Audit Report Lag and Corporate Governance in Malaysia, International Journal of Business and Management, Vol. 8 No. 15, pp. 151-163.

Ashton, R. H.; P.R. Graul; and J.D. Newton. 1989. Audit Delay and the Timeliness of Corporate Reporting. Contemporary Accounting Research, 5(2), 657-673.

Bamber, E. M.; L.S. Bamber; and M.P. Schoderbek. 1993. Audit Structure and Other Determinants of Audit Report Lag: An Empirical Analysis. Auditing: A Journal of Practice and Theory, 12(1), 1-23.

Be'dard, J. and Y. Gendron. 2010. Strengthening the Financial Reporting Systems: Can Audit Committees Deliver? International Journal of Auditing, 14(2), 1-37.

Che-Ahmad, A. and S. Abidin. 2008. Audit Delay of Listed Companies: A Case of Malaysia. International Business Research, 1(4), 32-39.

Cohen, J.; G. Krishnamoorthy; and A. M. Wright. 2002. Corporate Governance and the Audit Process. Contemporary Accounting Research, 19(4), 573-594.

Dalton, D.R.; C.M. Daily; J.L. Johnson; and A.E. Ellstrand. 1999. Number of Directors and Financial Performance: A Meta-Analysis. Academy of Management Journal, Vol. 42 No. 6, pp. 674-686.

Dibia, N.O. dan J.C. Onwuchekwa. 2013. An Examination of The Audit Report Lag of Companies Quoted in The Nigeria Stock Exchange. International Journal of Business and Social Research, Vol. 3 (9): 8-16.

Dimitropoulos, P.E. and D. Asteriou. 2010. The effect of board composition on the informativeness and quality of annual earnings: empirical evidence from Greece. Research in International Business and Finance. Vol. 24 No. 2, pp. 190- 205.

Fama, E. F. and M. C. Jensen. 1983. Separation of ownership and control. Journal of Law and Economics, 26(2), 301-325.

Forum for Corporate Governance in Indonesia. 2002. Corporate Governance

Giroux, G. and A.J. McLelland. 2000. An Empirical Analysis of Auditor Report Timing by Large Municipalities. Journal of Accounting and Public Policy, 19, 263-281.

Givoly, D. and D. Palmon. 1982. Timeliness of Annual Earnings Announcements: Some Empirical Evidence. The Accounting Review, 57(3), 485-508. 
Habib, A. and M.B.U. Bhuiyan. 2011. Audit Firm Industry Specialization and the Audit Report Lag. Journal of International Accounting, Auditing and Taxation, Vol. 20 No. 1, pp. 32-44.

Hashim, U.J. and R.A. Rahman. 2011. Board Independence, Board Diligence, Board Expertise and Impact on Audit Report Lag in Malaysian Market. Finance and Corporate Governance Conference 2011 Paper

Hassan, Y.M. 2016. Determinants of Audit Report Lag: Evidence from Palestine. Journal of Accounting in Emerging Economies. Vol. 6 No. 1, pp. 13-32.

Hussainey, K. and M. Wang. 2010. Voluntary Disclosure and Corporate Governance: Further UK Evidence. Working Paper, Stirling University, Stirling.

Ismail, K. N. I. and R. Chandler. 2004. The Timeliness of Quarterly Financial Reports of Companies in Malaysia. Asian Review of Accounting, 12(1), 1-18.

Iyoha, F.O. 2012. Company Attributes And The Timeliness Of Financial Reporting In Nigeria. Business Intelligence Journal, Vol. 5 (1): 41-49.

Kartika, A. 2009. Faktor-Faktor Yang Mempengaruhi Audit Delay Di Indonesia (Studi Empiris pada Perusahaan-Perusahaan LQ 45 yang Terdaftar di Bursa Efek Jakarta). Jurnal Bisnis dan Ekonomi, Vol. 16 (1): 1-17.

Lai, K.-W. and L.M.C. Cheuk. 2005. Audit Report Lag, Audit Partner Rotation and Audit Firm Rotation: Evidence from Australia. Working paper, Hong Kong Polytechnic University, Hung Hom, Hong Kong.

Lee, H. Y. and G. J. Jahng. 2008. Determinants of Audit Report Lag: Evidence from Korea An Examination of Auditor - Related Factors. Journal of Applied Business Research, Vol. 24 No. 2

Lee, H.Y.; V. Mande; and M. Son. 2009, Do Lengthy Auditor Tenure and the Provision of Non-Audit Services by the External Auditor Reduce Audit Report Lags? International Journal of Auditing, Vol. 13 No. 2, pp. 87-104.

Lim, C.-Y. and H.-T. Tan. 2010. Does Auditor Tenure Improve Audit Quality? Moderating Effects of Industry Specialization and Fee Dependence. Contemporary Accounting Research. Vol. 27 No. 3, pp. 923-957.

Lipton, M. and Lorsch, J.W. 1992. A Modest Proposal for Improved Corporate Governance. Business Lawyer, Vol. 59 No. 1, pp. 59-77

Dao, M. and T. Pham. 2014. Audit Tenure, Auditor Specialization and Audit Report Lag. Managerial Auditing Journal. Vol. 29 Issue: 6, pp.490-512, doi: 10.1108/MAJ-072013-0906

Mak, Y.T. and Y. Li. 2001. Seterminants of Corporate Ownership and Board Structure: Evidence from Singapore. Journal of Corporate Finance, Vol. 7 No. 3, pp. 235-256.

Mohamad-Nor, M. N; R. Shafie; and W.N. Wan-Hussin. 2010. Corporate Governance and Audit Report Lag in Malaysia. Asian Academy of Management Journal of Accounting and Finance, 6 (2), 57-84 
Naimi, M. N.; R. Shafie; and W.N. Wan-Hussin. 2010. Corporate Governance and Audit Report Lag in Malaysia. Asian Academy of Management Journal of Accounting and Finance, 6(2), 57-84.

O'Sullivan, N. 2000. The Impact of Board Composition and Ownership on Audit Quality; Evidence from large UK companies. The British Accounting Review, 32(4), 397-414

Owusu-Ansah, S. and S. Leventis. 2006. Timeliness of Corporate Annual Financial Reporting in Greece. European Accounting Review, 15(2), 273-287.

Panjaitan, Z.F.; Wahidahwati; and L. Amanah. 2013. Faktor-Faktor yang Mempengaruhi Audit Delay Dan Timeliness Atas Penyampaian Laporan Keuangan. Jurnal Ilmu and Riset Akuntansi. Vol. 2 (11): 1-18.

Rahmat, M. M.; T.M. Iskandar; and N.M. Saleh. 2009. Audit Committee Characteristics in Financially Distressed and Non-Distressed Companies. Managerial Auditing Journal, 24(7), 624-638.

Republik Indonesia. 1995. Undang-undang No. 8 Tahun 1995 tentang Pasar Modal. Lembaran Negara RI Tahun 1995, No. 64. Sekretariat Negara. Jakarta

Republik Indonesia. 2016. Salinan Peraturan Otoritas Jasa Keuangan No. 29/POJK.04/2016 tentang Laporan Tahunan Emiten Atau Perusahaan Publik. Lembaran Negara RI Tahun 2016, No. 150. Kementerian Hukum dan Hak Asasi Manusia. Jakarta

Saemargani, F.I. dan I. Mustikawati. 2015. Pengaruh Ukuran Perusahaan, Umur Perusahaan, Profitabilitas, Solvabilitas, Ukuran KAP, Dan Opini Auditor Terhadap Audit Delay. Jurnal Nominal, Vol. 4 (2): 1-15.

Salleh, Z., J. Steward, and S. Manson. 2006. The impact of board composition and ethnicity on audit quality: Evidence from Malaysian companies. Malaysian Acccounting Review, 5(2), 61-83.

Sugianto, D. (July, 31st 2017). BEI Suspensi 16 Saham Sekaligus. Detikfnance. (https://finance.detik.com/bursa-dan-valas/d-3580122/bei-suspensi-16-sahamsekaligus; downloaded on September, 10 ${ }^{\text {th }}, 2017$ )

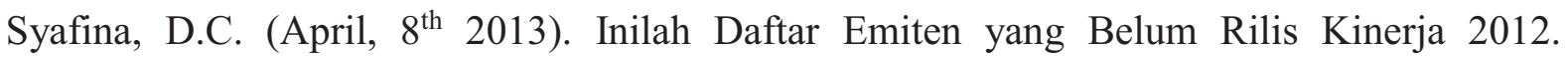
Kontan.co.id. (https://investasi.kontan.co.id/news/inilah-daftar-emiten-yang-belumrilis-kinerja-2012; downloaded on February, 14 ${ }^{\text {th }}, 2017$ )

Nelson, S.P. and S.N. Shukeri. 2011. Corporate Governance and Audit Report Timeliness: Evidence from Malaysia. Research in Accounting in Emerging Economies. 11(1).

Ika, S.R. and N.A.M. Ghazali. 2012. Audit Committee Effectiveness and Timeliness of Reporting: Indonesian Evidence. Managerial Auditing Journal. Vol. 27 Issue: 4, pp.403-424

Soltani, B. 2002. Timeliness of Corporate and Audit Reports: Some Empirical Evidence in the French Context. The International Journal of Accounting, 37, 215-246.

Turel, A. 2010. Timeliness of Financial Reporting in Emerging Capital Markets: Evidence from Turkey. Istanbul University Journal of the School of Business Administration, Vol. 39 (2): 227-240. 
$\mathrm{Wu}, \mathrm{C}$; C. $\mathrm{Wu}$; and V.W. Liu. 2008. The release timing of annual reports and board characteristics. The International Journal of Business and Finance Research, Vol. 2 No. 1, pp. 103-108.

Yaacob, N. and A. Che Ahmad. 2012. Adoption of FRS and Audit Delay in Malaysia. International Journal of Economics and Finance, 4 (1), 167-176. 